\title{
Challenges and Solutions for Enhancing Agriculture Value Chain Decision-Making. A Short Review
}

\author{
Hernandez JE ${ }^{1}$, Kacprzyk J ${ }^{2}$, Panetto $\mathrm{H}^{3}$, Fernandez A ${ }^{4}$, Liu S ${ }^{5}$, Ortiz A ${ }^{6}$ \\ and De-Angelis $\mathrm{M}^{7}$ \\ ${ }^{1}$ University of Liverpool Management School, UK. \\ ${ }^{2}$ IBSPAN, Systems Research Institute, Polish Academy of Sciences, POLAND. \\ ${ }^{3}$ UL, Université de Lorraine, FRANCE. \\ ${ }^{4}$ UNLP, Universidad Nacional de la Plata, ARGENTINA. \\ ${ }^{5}$ UoP, University of Plymouth, UK. \\ ${ }^{6} \mathrm{UPV}$, Universitat Politècnica de València, SPAIN. \\ ${ }^{7}$ The institute for Risk and Uncertainty, University of Liverpool, UK. \\ \{J.E.Hernandez\}@Liverpool.ac.uk
}

\begin{abstract}
Increasingly challenging global and environmental requirements have resulted in agricultural systems coming under increasing pressure to enhance their resilience capabilities. This in special to respond to the abrupt changes in resource quality, quantity and availability, especially during unexpected environmental circumstances, such as uncertain weather, pests and diseases, volatile market conditions and commodity prices. Therefore, integrated solutions are necessary to support the knowledge-management, collaborative ICT solution, risk management and regulation management across agriculture stakeholders. Therefore, and based on the on-going work under the H2020 RUC-APS project research network, this book chapter is oriented to contribute to agriculture value chain decision-making field to cover the current need on gathering a common understanding and appreciation of new trends in agriculture value chain, in special the multi-disciplinary challenges. For this, a short a literature review is conducted to summarise the main findings on real application and current research trends. This within the objective to propose an integrated framework based on better use of communication ways, standardised structures, development of training and awareness, regulation based initiatives and vertical Integration.
\end{abstract}

Keywords: Agriculture value chain, collaboration, ICT, Risk Management, case studies, review.

\section{Introduction}

In order to understand the agriculture concept from the operations and supply chain management perspective, the agribusiness terminology was established by [1] and can be understood as the sum of all operations involved in manufacture and distribution of farm supplies, production operations on the farm, and the storage, processing, and distribution of farm commodities. But, considering the current decision-making challenges in agribusiness, specially regarded to promote costless coordination of production and distribution, finding solutions to fixed market imperfections and consequent price distortions and how to include private strategies in agriculture and related sectors [2], uncertainties in information across the agribusiness related stakeholders have oriented agribusiness analyst to get focuses primarily on the 
following main topics: agricultural environment and resources; risk and uncertainty; food and consumer economics; prices and incomes; market structures; trade and development; and technical change and human capital. These topics remains open in terms of required support and solutions, but more important, open to support research from theory and practice. In this context, uncertainties in information implies noneeffective decision-making processes for farmers and to each related participant who belongs to the agriculture value chain.

In addition to this, and as established by [3], new kind of uncertainties coming from the climate global change issue is now another point of concern in agriculture and, even if it is a well-known issue, empirical research results has just been started to be released ([4-8]), but, even though, analysis on the main implications to agribusiness, decisionmaking, and collaborative networks in agriculture is still presented as a gap in the international literature. Thus, and as a source of uncertainty, climate change drives another type of uncertainties regarded to the lack of complete knowledge about the ecosystems reactions to climate change. This has important implications on how decision-making approaches are to be adapted to these new challenges. In fact, one of the main goals in agriculture and for the whole agri-food sector, is to find the right responses and strategies to the agribusiness challenges in a much faster way [9], but also dealing with the main uncertainties collaboratively. In addition to this, it is important to consider the role that farmers can play in overcoming these uncertainties if they are supported accordingly. This means providing them the right guidance, information, training and collaborative approach for developing solutions to their problems. But, due to the lack of information (specially regarded to the local regions cultures), this is certainly becoming a major task every day more. Thus, and considering current agribusiness based framework analysis done by [10] and [11], practitioners and researcher are still looking at finding the efficient ways to answer questions like: how current growing in risk and uncertainty affects agribusiness stakeholders?; is the development and adoption of new technologies adding value to agribusiness related activities?, how can rapid market responsiveness be implemented so support changes in industry structure? and; are collaborative networks applicable in agribusiness domains to deal with interoperable aspects?

Therefore, in the light of these current open challenges in agribusiness, the aim of this research is to provide an up-to-date contribution to field of Agriculture Value Chain decision-making, in special by updating and contrasting main challenges and requirements based on current literature and case studies. To accomplish this, the rationale is supported by considering following structure: (1) in the second section the research method is explained; next (2) the brief literature review on cases, knowledge management, collaborative ICT, risk management, regulations in agriculture value chain management is presented; after this (3) a brief analysis is presented in the section four within the purpose of addressing the main recommendations, from research, in order to support the main challenges and requirements from agriculture value chains, thus the RUC-APS framework is proposed and; finally (4) main conclusions and further research is presented. 


\section{Research Method}

Considering the existing literature review in the field already performed by [3, 12-21], the method to support this review will consider sources from journals, books and reports in field of agriculture within a view of: value chain, ICT, risk, regulations and case studies. For this purpose, a qualitative analysis is to be performed to provide the current pictures on the already mentioned challenges. The main selected sources for this review are: $\quad$ http://scholar.google.com, $\quad$ http://www.scopus.com $\quad$ and http://www.sciencedirect.com.

Therefore, the main objective from this brief literature review is identify the main gaps and trend in the current research, understand the main agriculture value chain challenges and requirements, realise how theory and method is supported by empirical evidence and to understand how the main application are taking place in the field. The main findings from this research are presented in the following sections.

\section{Short Literature Review on Challenges and Solutions for Enhancing Agriculture Value Chain Decision-Making}

Regarding to the findings in agriculture needs from [30], it was shown that nearly a third of the global population relies on agriculture for a living, and the growth in this sector has been at least twice as effective at reducing poverty as growth in other sectors. But, progress on agriculture-based solutions can be frustratingly slow, therefore practitioners, researchers and academics are every day more involved in this field. In fact, challenges in agriculture might vary from biological science, going through healthcare to social science and technologies. Which topics has been extensible reviewed [2227]. But also, from the agribusiness decision-making point of view [28, 29], there is a high need for generating integrated and collaborative solutions, so that farmers can be embedded in the participative solutions generation process. Therefore, this review section is to be focused on decision-making process related to agriculture value chains.

In fact, a high variety of new digital applications, oriented to accelerate the improvement on productivity and growth in this sector [30], can be found, but not all of them are effective or resilient enough once agriculture value chains are facing unexpected events. As a tool, ICTs can provide the forum to access information and the necessary training to agriculture value chain stakeholders by enhancing their communication strategies, thus their decision-making process. ICTs will consist of electronic and digital based solutions for capturing, processing, sharing, storing and retrieving information, hence for broadcasting and using data and images through technology based mechanism [31]. In this context, the dilemma in most of the agriculture domains is regarded to decide and realise whether to move towards to a more traditional, organic farming or to a modern biotechnology-based agriculture [32], which necessarily implies the combined use of: Knowledge Management, ICT, Collaborative solutions, Decision Support Systems and regulation management. However, the scenario is even more complex, and a well and up-to-date understanding is required.

In fact, whether a wide variety of agricultural technologies and sustainability pathways are required to co-exist (worldwide at least), the current need from agriculture 
value chain stakeholders have moved from choosing between existing technologies to focus on the new technological developments through innovation [33]. But this has also led to the wide unused number of technologies as well the clueless from farmers about what the main criteria for selected the right solution might be. Therefore, by considering agriculture value chains market's needs, agri-food supply (farmers and manufacturers) and demand (supermarkets and other food retailers) established by [34], the following section presents the key findings in author contributions. This starts by considering we challenges addressed for veridical collaboration, information sharing and climate change within a view of agriculture value chain. From this perspective, and considering the current agribusiness value chain challenges, papers were reviewed and selected. Regarding to this, agribusiness decision-making related paper were selected on the key following domains: Collaborative ICT, Risk Management, Ontology driven, Technology transfer, Regulation analysis considering the following approaches: Supply chain management, Multi-stakeholder, Decision Support System, Real-life, Case study.

\subsection{Case Studies Analysis in Agriculture Value Chains Decision-Making Challenges}

There are many challenges involved in the agriculture value chains. These challenges can be seen from several angles and their implication can be grouped in three main themes, such as: vertical integration, information sharing and regarding the uncertainties due to the climate change. From this analysis is depicted that since the 80 's there is a continuous interest for developing solutions to support these challenges. In overall, the analysis considers references that discusses the agriculture value challenges from a real-life case study point of view (see Table 1).

Table 1. Case Studies based on main agriculture value chains decision-making challenges.

\begin{tabular}{|c|c|c|}
\hline Author & Agriculture value chain decision-making challenges & $\begin{array}{c}\text { Main } \\
\text { aspect to } \\
\text { support }\end{array}$ \\
\hline$[35]$ & $\begin{array}{l}\text { India horticulture industry has ineffective information } \\
\text { communication between producers and end-customers. The } \\
\text { government introduced a physical wholesale market terminal to } \\
\text { allow producer and end-customers to meet and share information }\end{array}$ & $\begin{array}{l}\text { Vertical } \\
\text { Integration }\end{array}$ \\
\hline$[36]$ & $\begin{array}{l}\text { Both wholesalers and retailers need to know producers and } \\
\text { production information. }\end{array}$ & $\begin{array}{l}\text { Vertical } \\
\text { Integration }\end{array}$ \\
\hline$[37]$ & $\begin{array}{l}\text { Most farmers use wire phone or cellular phone to seek information. } \\
\text { The Internet is not a popular method as lack of infrastructure, the }\end{array}$ & $\begin{array}{l}\text { Information } \\
\text { Sharing }\end{array}$ \\
\hline
\end{tabular}
cost of using the internet and the literacy rate of farmers.

Sharing

Farmers need a wide range of information to make a good decision.

[38] Information for farmers is very fragmented and unreliable. It is suggested to use a database that store information all together to facilitate farmers' decision making.

Information

Sharing

39] The common way for India farmers to get reliable information is to go to external organisations. External organisations are usually far

Information

Sharing 


\begin{tabular}{|c|c|c|}
\hline Author & Agriculture value chain decision-making challenges & $\begin{array}{l}\text { Main } \\
\text { aspect to } \\
\text { support }\end{array}$ \\
\hline & $\begin{array}{l}\text { from farmers. Farmers need to drive there and it is very costly and } \\
\text { time-consuming. The access to information is restricted or } \\
\text { prohibited. Access to digital information is a bottleneck for HVC } \\
\text { performance improvement in India. }\end{array}$ & \\
\hline$[40]$ & $\begin{array}{l}\text { Choosing the right are for growing vegetable is a major issue. In } \\
\text { special under climate change, hence it is suggested to use } \\
\text { information communication between nation, regional and local-level } \\
\text { management. }\end{array}$ & $\begin{array}{l}\text { Climate } \\
\text { change }\end{array}$ \\
\hline [41] & $\begin{array}{l}\text { Under a Value Chain Approach, environmental parameters, such as } \\
\text { temperature, affects the product cycle time, in this case the example } \\
\text { of grape was studied, where it was realised the agriculture value } \\
\text { chain, due to high temperatures was required now to deal with 's } \\
\text { faster ripening process time. }\end{array}$ & $\begin{array}{l}\text { Climate } \\
\text { change }\end{array}$ \\
\hline [42] & $\begin{array}{l}\text { Weather tracking database predicts the weather and makes planning } \\
\text { arrangement, which successfully improves the effectiveness of } \\
\text { producing quality grape. }\end{array}$ & $\begin{array}{l}\text { Climate } \\
\text { change }\end{array}$ \\
\hline [43] & $\begin{array}{l}\text { The quality of vegetable will be indirectly affected by climate } \\
\text { change due to the change of pest species. A model shows the } \\
\text { relationship between the temperature and the species of pests helps } \\
\text { predict and control pest in agriculture. }\end{array}$ & $\begin{array}{l}\text { Climate } \\
\text { change }\end{array}$ \\
\hline
\end{tabular}

As depicted in Table 1, it can be found that vertical Integration and information sharing are two topics widely discusses, as well climate change. In addition, it is also possible to realise that authors also address ICT aspects to be considered once setting up potential solutions to food contamination problem, food security policies and postharvest practices, where the main objective in supporting these challenges is to ensure the food quality and safety.

In addition to this, one of the key identified challenges is regarded on how managing the knowledge across the agriculture value chain and their stakeholders. This since the level of tacit knowledge is very high, thus the main solution for these challenges will be around gathering the tacit knowledge to make it explicit. Therefore, the knowledge management might be contrasted across the agriculture value chain stakeholders, thus be used for developing more efficient solutions. For this purpose, the following section, by considering the knowledge management aspects, gather the number of authors contributing to the combined perspective of Knowledge Management, Collaborative ICT, Risk Management, Ontology driven, Technology transfer and Regulation analysis; versus Supply chain management, Multi-stakeholder, Decision Support System, Real-life and Case study. 


\subsection{Knowledge Management, Collaborative ICT, Technology Transfer and Risk Analysis Contributions to Agriculture Value Chain}

From Table 1 analysis, it is depicted that the main challenges remain on how to determine the right selection and application of existing and emerging technologies, as well as on how to consider the adequate ongoing R\&D for small farmers at small-scale food processing operations, therefore to move toward reducing the cost of food. But this also within an special focus of making a significant contribution to food production, environment and also to provide a good living for the operators/farmers [34]. From this, it also important to consider that due to the great advancement on ICTs, a high advancement in agriculture planning has ben also produced. One of the reasons for this is due to the fact that, ICT's can not only be cost-effectively and practically employed to facilitate information delivery, but also to support an effective knowledge sharing among farmers and stakeholders [44]. Hence, the success of agriculture value chain will necessarily depends largely on decisions by stakeholders on questions such as what to grow, where to sell, how to maintain the main sources, and how to manage common resources [45].

It is also acknowledged that stakeholders, involved in agricultural and rural development, are highly required to communicate, negotiate and to reach decisions that can achieve results. The main failures are commonly regarded to the extension on inability to deal with communication concerns. In fact, and based on [46], works at the farming/producer level are often ineffective in their communication with partners, which is due to the lack in training in methods of communication. They often have technical, but not communication orientation [47], which generated an unbalanced situation. Thus, and due to the variety of uncertainty sources in weather, soil, water and land conditions, diverse models, methods of analysis and solutions are needed on which the knowledge from farmers will be gathered and manged accordingly. This will activate the need of using different ways to support the variety of challenges in agriculture value chains, but in special to develop usable solutions to farmers [48]. Nevertheless, with the rapid development of information technology, the agriculture information dissemination models are constantly evolved and required of analysis for solutions [19]. Table 2 shows, therefore, the main findings for Supporting Agriculture Value Chain Decision-making considering a multidisciplinary approach.

Table 2. Contribution analysis to Agriculture value chain decision-making.

\begin{tabular}{lcccc}
\hline $\begin{array}{l}\text { Dimension/ } \\
\text { approach }\end{array}$ & $\begin{array}{c}\text { Supply chain } \\
\text { management }\end{array}$ & $\begin{array}{c}\text { Multi- } \\
\text { stakeholder }\end{array}$ & $\begin{array}{c}\text { Decision Support } \\
\text { System }\end{array}$ & $\begin{array}{c}\text { Real-life } \\
\text { Case study }\end{array}$ \\
\hline $\begin{array}{l}\text { Knowledge } \\
\text { Management }\end{array}$ & {$[30],[32],[49]$} & {$[47],[49],[50]$} & {$[47],[51],[52]$} & $\begin{array}{c}{[12],[18],[30],} \\
{[49],[50],[47]}\end{array}$ \\
$\begin{array}{l}\text { Collaborative } \\
\text { ICT }\end{array}$ & {$[19],[20],[53]$,} & {$[14],[53],[56]$,} & {$[15],[20],[51],[53]$,} & {$[12],[21],[30]$,} \\
& {$[54],[55]$} & {$[57]$} & {$[58],[59],[60]$} & {$[58],[61],[62]$}
\end{tabular}




\begin{tabular}{|c|c|c|c|c|}
\hline $\begin{array}{l}\text { Dimension/ } \\
\text { approach }\end{array}$ & $\begin{array}{l}\text { Supply chain } \\
\text { management }\end{array}$ & $\begin{array}{c}\text { Multi- } \\
\text { stakeholder }\end{array}$ & $\begin{array}{c}\text { Decision Support } \\
\text { System } \\
\end{array}$ & $\begin{array}{c}\text { Real-life } \\
\text { Case study }\end{array}$ \\
\hline $\begin{array}{l}\text { Risk } \\
\text { Management }\end{array}$ & [17], [55] & [17], [63], [64], & [17], [65] & $\begin{array}{c}{[17],[63],[64],} \\
{[65]}\end{array}$ \\
\hline $\begin{array}{l}\text { Ontology } \\
\text { driven }\end{array}$ & $\begin{array}{c}{[48],[55],[66],} \\
{[67],[68],[69]}\end{array}$ & $\begin{array}{c}{[63],[66],[68],} \\
{[70]}\end{array}$ & $\begin{array}{c}\text { [66], [68], [69], [71], } \\
{[72],[70]}\end{array}$ & $\begin{array}{c}{[48],[63],[67],} \\
{[69],[71],[72]}\end{array}$ \\
\hline $\begin{array}{l}\text { Technology } \\
\text { transfer }\end{array}$ & {$[30],[73]$} & $\begin{array}{c}{[12],[73],} \\
{[74],[75]}\end{array}$ & [12] & $\begin{array}{c}\text { [64], [73], [75], } \\
{[76],}\end{array}$ \\
\hline $\begin{array}{l}\text { Regulation } \\
\text { analysis }\end{array}$ & {$[15],[33],[48]$} & {$[63],[77],[78]$} & [74], [78] & {$[63],[78]$} \\
\hline
\end{tabular}

Aligned with this, table 2 shows where the key authors contribute to the main areas. Thus, it depicts the fact that, in general the agriculture value chain is widely known, and a variety of solutions and approaches are considered to overcome most of the challenges.

Nevertheless, not all the approaches are considered in the same way, and certainly they do not weight the same. This is the clear case of Collaborative ICT and Regulation analysis. In fact, where collaborative solutions are required at every level, there is an evidence that regulations advancement are not always aligned and up-to-date with these requirements. In addition to this, whether the application based research marks a high presence on authors contributions, it is also evidence the connection from theory and practice is low. This means that contributions on theory are still a pending matter once looking at real-life applications. Whether theory in operational research and ICT developments are high, these are good under a theoretical aspect, but lacks on applicability. Moreover, the development of decision support systems is also wide, and most of the researchers look at its applications, but just a few look at the value chain and/or multi-stakeholders approach. Which means the challenges on developing collaborative and participatory agriculture value chain decision support systems remains as an open topic. An interesting aspect was the evidenced on using/creating ontologies for supporting the ICT development of agriculture value chain solutions. Nevertheless, even if a variety of cases can be found in this topic, the use of ontologies still lacks on their real applicability, in especial to support the technology transfer aspects and interoperability across agribusiness technologies. In fact, decision support systems based training on agriculture value chain stakeholders is a key aspect, but has been vaguely covered by research authors and it is depicted as one of the less covered topics, thus a high level of opportunities for enhancing this topics as a research theme in agriculture value chain is depicted.

\section{Analysis}

From the short literature review, and aligned with the contribution from [79], it is realised that main barriers for adopting ICT solutions are: (1) the lack of physical and 
human resource infrastructure, (2) too much innovation blocks the use of older tested and in use technologies imposing an unacceptable cost, (3) ICT adoption based on working within communities takes longer in many cases because of the lack of understanding and awareness of the needs and challenges of small-scale farmers, (4) Ensuring leadership within the political and governmental environment, (5) Developing leadership and agents of change at all levels including communities, (6) Sharing ICT adoption funding including public/private partnership and (7) Sharing details of successful projects including business opportunities and their benefits.

Therefore, at the agriculture value chain level, the creation of efficient agricultural market, which delivers agricultural products, from the farmer to the consumer is a need. This implies that, behind every challenge and contributions, there is a need for efficiently make functioning agriculture value chains to commit with the markets, thus to make producers and consumers increase their benefits. But unfortunately, the supply chain management models are not as efficient as desired, and ICT integrations are still an open requirement to support the agribusiness based decision-making.

The challenges facing supply-chain management and agri-business can be seen from three main perspectives. In the first place, the lack of accessibility to regulated markets generates difficulties to establish standardised agriculture value chains solutions. In the second place, the lack of participatory developments, implies a lack on effective ICT developments for Agriculture value chain stakeholders, specially farmers. Finally, lack on standard regulations that understand the micro-levels of the value chain, implies inefficiencies across the value chain stakeholders.

In this context, from the reviewed papers, and by analysing and understating the main implications from coming from Tables 1 and 2, the following suggestions for supporting the current challenges and solution generations for enhancing the Agriculture Value Chain Decision-making are addressed:

- Better use of communication ways: Once the Agriculture value chain is formed, and in order meet their desired objectives efficiently, the information sharing is essential, thus collaborative ways must be set in place, specially to monitor and trace information between stakeholders.

- Set standardised structures: Through standardised structures it will possible to achieve more effectively the efficiency desired levels. In this context, standards might follow two approaches: (1) the first is regarded on how the agriculture products are produced, packaged, transported and delivered; (2) the second is regarded to ICT systems to be used across the value chain. Therefore, these standard approaches will enable stakeholders to efficiently manage their inefficiencies as well as to interoperate better with the high variety of systems available on these agriculture value chain environments.

- Development of training and awareness: Due to the current changes and evolution on market needs, hence into agriculture value chain structures, specialists, that will understand the high variety of value chain structures, is required. Hence, training, coaching, counselling and mentoring can be extended to all the parties in the supply chain. In this way, collaborative ICT solution might be better applied in several levels of the value chain.

- Regulation based initiatives: Agriculture regulations plays a leading role, in special with the new globalisation trends. International value chains are everyday more common; hence, robust and adaptable regulations are required to deal 
effectively with unexpected uncertainties from each region. The objective of this approach, is to generate consistent agriculture value chains across every level, thus to mutually reinforce them and commit with the common contradictory objectives from regions and stakeholders, therefore, standard protocols (ontologies) must be in place to support collaborative ICT, Risk management and regulation development.

- Vertical Integration: Considering the new trends on technologies as well as the dynamics of world economy, agribusiness stakeholders, in special farmers, are required to get collaborative involved, so that the continuous provision of safe and ample raw materials can be guaranteed amongst farmers, processors and traders. Therefore, the vertical integration will promote shorter value chains and an increment on total returns shares. Therefore, to cope with the main uncertainties, farmers will get more incentives to achieve value chain requirements, such as certifications and global environmental requirements. Therefore, agriculture stake holder will be in a better position to use standardised technologies to share information and support collaborative decision-making processes.

\subsection{The RUC-APS Framework proposal}

Therefore, to provide a crystallised view on how a potential solution might looks like, the Fig. 1 presents the RUC-APS framework. Through this, an advancement in agriculture based-decision making is provided. Thus, the agriculture value chain will be seen in terms of the integration of Global Agribusiness, Risk and Uncertainty, enduser driven solutions, inputs, products for exports, packaging \& cold storage, processing and distributions. Therefore, the agriculture production systems, and its impact over the end users, will be mainly driven by participatory ICT developments.

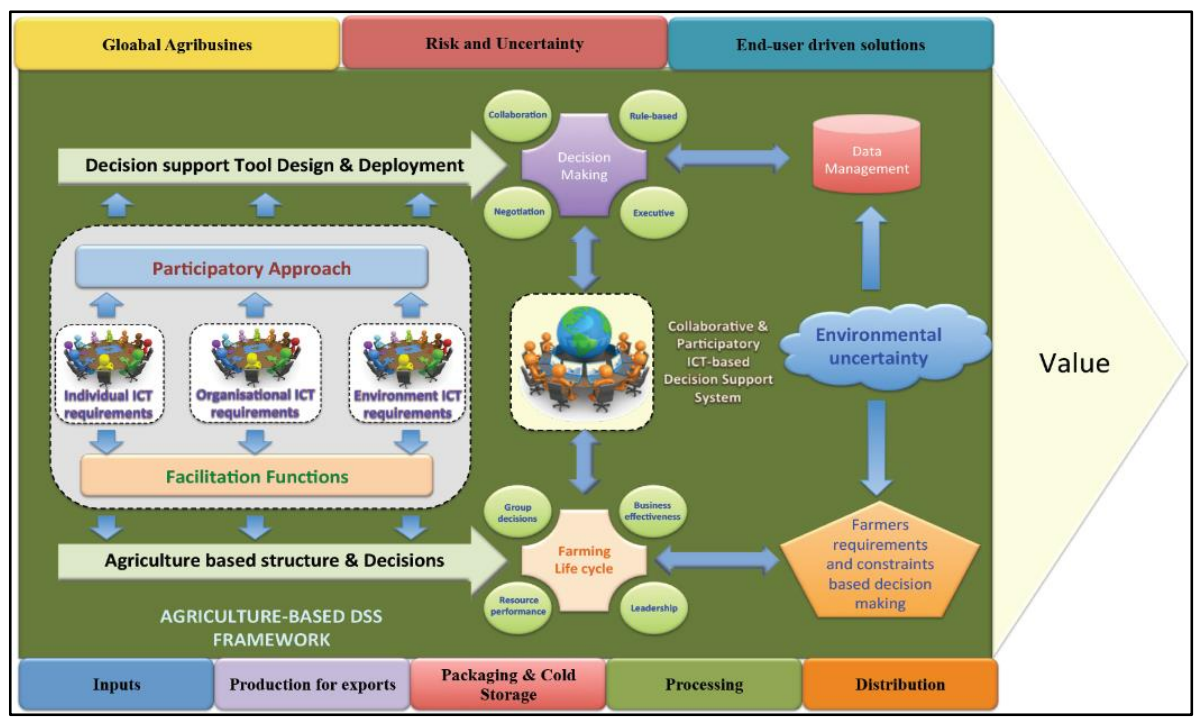

Fig. 1. The RUC-APS Framework (sources: www.ruc-aps.eu). 
As depicted in Fig. 1, the RUC-APS framework is oriented to contribute to the generation of horizontal and vertical collaboration strategy for supporting agriculture value chain in terms of: the organisations development for building mutual and beneficial value chain relationships in agriculture. For this the proposed RUC-APS framework propose enhancing the interactions between small and medium farmers with major value chain actors (often smallholders and businesses in the upstream chain segment) and larger, better-endowed businesses further downstream; and, to integrate this with policies that will support the environment on which value chain actors operate. Therefore, RUC-APS provide innovation for the development of agriculture production systems and their impact over the end-users by focusing on participatory ICT developments.

\section{Conclusions}

From this brief literature review, it can be realised that there is a clear evidence that current growing in risk and uncertainty are affecting affects agribusiness stakeholders' decision-making, especially in terms of dealing with the key commodities, such as price. Thus, if the supply chain management is improved in the agriculture sector, it will lead farmers to improve their business scenario. In fact, the key aspects addressed from authors were vertical integration, information sharing and climate changes, as main source of current challenges to be supported.

In this sense, it was noticed that one of the critical aspect to improve the agriculture supply chain management is the one regarded to adoption of new technologies, which necessarily implies that the information flow should be managed standardly. This will enhance the information sharing, thus will create value and will improve the performance, even more once information sharing will be established across regions and sectors, hence rapid responses to the market will be required. In fact, as depicted from the reviewed literature, the major reasons causing information sharing issues are that producers not always have access to the right ICT, hence access to information is not that straight, which implies a current need in implementing collaborative network structure to deal with ICT interoperable aspects.

Another aspect is that agriculture value chains are facing is climate change, which implies a higher need for collaboration to overcome the main uncertainties, in special amongst stakeholders from similar latitudes. From this point of view, nearly all solutions which have considered a knowledge management point of view, presented an effective information flow, thus a better agriculture value chain performance. In addition to this, there was a clear evidence that authors dealing with knowledge management were more inclined to share more information, hence to improve their performance.

Finally, from the authors contribution analysis, it can be also concluded that ICT solutions for agriculture problems aims to increase information accessibility, variety, sharing to stakeholders, and present a relevant contribution to farmers, thus presenting a high potential of increasing the decision-making efficiently. As a further research, considering the RUC-APS project activities, this short review will be extended by supporting the generation of a validated agriculture value chain conceptual model for 
the main stakeholders' decision-making and the main ICT application will be addressed for the seven countries on which the project is being applied (UK, Spain, Italy, France, Poland, Chile and Argentina). In addition, an extended version of this literature review will be produced by analysing more international case studies and adding quantitative analysis for this review, as well as by establishing the most up-to-date agriculture value chain road-map and covering the main interoperability due the main agriculture value chain integration requirements.

Acknowledgments. Authors of this publication acknowledge the contribution of the Project 691249, RUC-APS: Enhancing and implementing Knowledge based ICT solutions within high Risk and Uncertain Conditions for Agriculture Production Systems (www.ruc-aps.eu), funded by the European Union under their funding scheme H2020-MSCA-RISE-2015.

\section{References}

1. Davis, J., Goldberg, R.: A concept of agribusiness. Division of research. Graduate School of Business Administration. Bost. Harvard Univ. (1957).

2. Zylbersztajn, D.: Agribusiness systems analysis: origin, evolution and research perspectives. Rev. Adm. (2016).

3. Yousefpour, R., Jacobsen, J., Thorsen, B., Meilby, H.: A review of decision-making approaches to handle uncertainty and risk in adaptive forest management under climate change. Ann. For. (2012).

4. Myers, S., Smith, M., Guth, S., Golden, C.: Climate Change and Global Food Systems: Potential Impacts on Food Security and Undernutrition. Annu. Rev. (2017).

5. Thamo, T., Addai, D., Pannell, D., Robertson, M.: Climate change impacts and farm-level adaptation: Economic analysis of a mixed cropping-livestock system. Agricultural. (2017).

6. Altieri, M., Nicholls, C.: The adaptation and mitigation potential of traditional agriculture in a changing climate. Clim. Change. (2017).

7. Alam, M., Siwar, C., Murad, M., Toriman, M.: Impacts of climate change on agriculture and food security issues in Malaysia: an empirical study on farm level assessment. (2017).

8. Lobell, D., Asseng, S.: Comparing estimates of climate change impacts from process-based and statistical crop models. Environ. Res. Lett. (2017).

9. Yearbook, F.: World food and agriculture. Food Agric. Organ. United. (2013).

10. McKenzie, F., Williams, J.: Sustainable food production: constraints, challenges and choices by 2050. Food Secur. (2015).

11. Boehlje, M., Roucan-Kane, M., Bröring, S.: Future agribusiness challenges: Strategic uncertainty, innovation and structural change. Int. Food. (2011).

12. Suprem, A., Mahalik, N., Kim, K.: A review on application of technology systems, standards and interfaces for agriculture and food sector. Comput. Stand. Interfaces. (2013).

13. Mahmood, H., Ahmad, M., Ahmad, T.: Potentials and prospects of precision agriculture in Pakistan-a review. Pakistan J. Agric. (2013).

14. Kruize, J.W., Robbemond, R.M., Scholten, H., Wolfert, J., Beulens, A.J.M.: Improving arable farm enterprise integration - Review of existing technologies and practices from a farmer's perspective. Comput. Electron. Agric. 96, 75-89 (2013).

15. Martin, G., Martin-Clouaire, R., Duru, M.: Farming system design to feed the changing world. A review. Agron. Sustain. (2013).

16. Aqeel-Ur-Rehman, Abbasi, A.Z., Islam, N., Shaikh, Z.A.: A review of wireless sensors and networks' applications in agriculture, http://www.sciencedirect.com/science/article/pii/S0920548911000353, (2014). 
17. Zougmoré, R., Partey, S.: Toward climate-smart agriculture in West Africa: a review of climate change impacts, adaptation strategies and policy developments for the livestock, fishery. Agric. (2016).

18. Dercon, S., Gollin, D.: Agriculture in African Development : A Review of Theories and Strategies. Annu. Rev. Resour. Econ. 44, 1-41 (2014).

19. Zhang, Y., Wang, L., Duan, Y.: Agricultural information dissemination using ICTs: A review and analysis of information dissemination models in China. Inf. Process. Agric. 3, 17-29 (2016).

20. Kaur, H., Goraya, S.: Role of Cloud Based Technologies in Agriculture Process Across Countries: A Review. Int. J. Comput. Sci. (2016).

21. Gangurde, P., Bhende, M.: A Review on Precision agriculture using Wireless Sensor Networks. Int. J. Eng. Trends Technol. 23, 426-431 (2015).

22. Mittler, R., Blumwald, E.: Genetic engineering for modern agriculture: challenges and perspectives. Annu. Rev. Plant Biol. (2010).

23. Opara, L.: Traceability in agriculture and food supply chain: a review of basic concepts, technological implications, and future prospects. J. Food Agric. Environ. (2003).

24. Hillocks, R.: Farming with fewer pesticides: EU pesticide review and resulting challenges for UK agriculture. Crop Prot. (2012).

25. Shalaby, M., Al-Zahrani, K., Baig, M.: Threats and challenges to sustainable agriculture and rural development in Egypt: implications for agricultural extension. J. Anim. (2011).

26. Pant, L., Hambly-Odame, H.: Innovations systems in renewable natural resource management and sustainable agriculture: a literature review. African J. Sci. Technol. (2009).

27. Nagpure, A., Choudhary, B., Gupta, R.: Chitinases: in agriculture and human healthcare. Crit. Rev. (2014).

28. Iglesias, A., Quiroga, S., Moneo, M., Garrote, L.: From climate change impacts to the development of adaptation strategies: challenges for agriculture in Europe. Clim. Change. (2012).

29. Irvin, R., Stansbury, J.: Citizen participation in decision making: Is it worth the effort? Public Adm. Rev. (2004).

30. Warshauer, W.: How Digital Is Solving Three Problems in Agriculture | TechnoServe Business Solutions to Poverty, http://www.technoserve.org/blog/how-digital-is-solvingthree-problems-in-agriculture.

31. Zappacosta, M.: Information technologies for rural development: between promises and mirages. info. 3, 521-534 (2001).

32. de Wilt, J.G., Diederen, P.J.M., Butter, M., Tukker, A.: Innovation challenges for European agriculture. Foresight. 3, 341-352 (2001).

33. Viaggi, D.: Research and innovation in agriculture: beyond productivity? Bio-based Appl. Econ. (2015).

34. Lee, J., Gereffi, G., Beauvais, J.: Global value chains and agrifood standards: challenges and possibilities for smallholders in developing countries. Proc. Natl. Acad. Sci. U. S. A. 109, 12326-31 (2012).

35. Mittal, S.C.: Role of Information Technology in Agriculture and its Scope in India.

36. Dolan, C., Humphrey, J.: Governance and Trade in Fresh Vegetables: The Impact of UK Supermarkets on the African Horticulture Industry. J. Dev. Stud. 37, 147-176 (2000).

37. Gummagolmath, K., Sharma, P.: User Centric ICT Model for Supply Chain of Horticultural Crops in India. Agric. Econ. Res. Rev. 26, 91-100.

38. Awuor, F., Kimeli, K., Rabah, K., Rambim, D.: ICT Solution Architecture for Agriculture. Conf. Proc. 978-1 (2013).

39. Rao, N.H.: A framework for implementing information and communication technologies in agricultural development in India.

40. Challinor, A., Wheeler, T., Garforth, C., Craufurd, P., Kassam, A.: Assessing the 
vulnerability of food crop systems in Africa to climate change. Clim. Change. 83, 381-399 (2007).

41. Jones, G., Davis, R.: Climate influences on grapevine phenology, grape composition, and wine production and quality for Bordeaux, France. Am. J. Enol. (2000).

42. Webb, L., Whetton, P., Barlow, E.W.R.: Modelled impact of future climate change on phenology of wine grapes in Australia. Aust. J. Grape Wine Res. 13, 165-175 (2007).

43. Thomson, L.J., Macfadyen, S., Hoffmann, A.A.: Predicting the effects of climate change on natural enemies of agricultural pests. (2009).

44. Annor-Frempong, F., Kwarteng, J., Agunga, R., Zinnah, M.M.: Challenges and prospects of infusing information communication technologies (ICTs) in extension for agricultural and rural development in Ghana. J. Ext. Syst. 23, 36-46 (2006).

45. Rivera, W., Alex, G.: Agriculture and Rural Development Discussion Paper 12 Extension Reform for Rural Development. (2004).

46. Röling, N.G.: Extension science: information systems in agricultural development. Cambridge University Press (1988).

47. Vod Ät, K.W., Kuiper, D., Röling, N.: The edited proceedings of the European Seminar on Knowledge Management and Information Technology. (1989).

48. ur Rehman, A.: Smart Agriculture: An Approach Towards Better Agriculture Management. (2015).

49. McCullough, E., Matson, P.: Evolution of the knowledge system for agricultural development in the Yaqui Valley, Sonora, Mexico. Proc. Natl. (2016).

50. Zewge, A., Dittrich, Y.: Systematic mapping study of information communication technology research for agriculture (in case of developing Countries). (2015).

51. Rose, D., Sutherland, W., Parker, C., Lobley, M.: Decision support tools for agriculture: Towards effective design and delivery. Agricultural. (2016).

52. Barlett, P.: Agricultural decision making: Anthropological contributions to rural development. (2016).

53. Jain, L., Kumar, H., Singla, R.: Localization of information dissemination in agriculture using mobile networks. Crit. Infrastruct. Proc. .... (2014).

54. Holzworth, D., Huth, N., Zurcher, E., Herrmann, N.: APSIM-evolution towards a new generation of agricultural systems simulation. Model. Softw. (2014).

55. Berger, T., Troost, C.: Agent-based Modelling of Climate Adaptation and Mitigation Options in Agriculture. J. Agric. Econ. n/a-n/a (2013).

56. The Guardian: How ICT tools are improving efficiency of agricultural development | Global Development Professionals Network | The Guardian, https://www.theguardian.com/global-development-professionalsnetwork/2013/jan/24/data-collection-evaluation-technology-agriculture.

57. CARDI: Regional Synthesis of ICT Uptake and Usage in Agricultural Value Chains in the Caribbean. (2015).

58. Lipper, L., Thornton, P., Campbell, B., Baedeker, T.: Climate-smart agriculture for food security. Nat. Clim. (2014).

59. Mbũgwa, G. wa, Prager, S., Krall, J.: Utilization of spatial decision support systems decision-making in dryland agriculture: A Tifton burclover case study. Electron. Agric. (2015).

60. Kaloxylos, A., Groumas, A., Sarris, V., Katsikas, L.: A cloud-based Farm Management System: Architecture and implementation. Electron. Agric. (2014).

61. Patel, H., Patel, D.: SURVEY OF ANDROID APPS FOR AGRICULTURE. Int. J. Inf. (2016).

62. Williams, T., Mul, M., Cofie, O., Kinyangi, J.: Climate Smart Agriculture in the African Context. (2015).

63. Banson, K., Nguyen, N.: Using system archetypes to identify drivers and barriers for sustainable agriculture in Africa: a case study in Ghana. Syst. Res. (2016). 
64. Rosenzweig, C., Elliott, J., Deryng, D.: Assessing agricultural risks of climate change in the 21 st century in a global gridded crop model intercomparison. Proc. (2014).

65. Pham, H.: Design of environmental performance measurement systems for agriculture. (2016).

66. Walisadeera, A., Wikramanayake, G.: An ontological approach to meet information needs of farmers in Sri Lanka. Comput. Sci. .... (2013).

67. O'Leary, D.: A multilingual knowledge management system: A case study of FAO and WAICENT. Decis. Support Syst. (2008).

68. Kawtrakul, A.: Ontology engineering and knowledge services for agriculture domain. J. Integr. Agric. (2012).

69. Xie, N., Wang, W.: Ontology and acquiring of agriculture knowledge. Agric. Netw. Inf. (2007)

70. ZHENG, Y., HE, Q., Ping, Q., Ze, L.: Construction of the ontology-based agricultural knowledge management system. J. Integr. Agric. (2012).

71. Song, G., Wang, M., Ying, X., Yang, R., Zhang, B.: Study on precision agriculture knowledge presentation with ontology. AASRI Procedia. (2012).

72. Alfred, R., Chin, K., Anthony, P., San, P., Im, T.: Ontology-based query expansion for supporting information retrieval in agriculture. 8th Int. (2014).

73. Ahuja, L.R., Ma, L., Howell, T.A.: Agricultural system models in field research and technology transfer. (2002).

74. Ploss, S.: Conflict and decision-making in Soviet Russia: a case study of agricultural policy, 1953-1963. (2015).

75. Norris, W.C.: Responding to the technological challenges of small scale agriculture [Text of speech presented at the banquet of the Beltsville Agricultural Research Center Special Symposium Research for Small Farms, November 17, 1981]. Misc. Publ. - U.S. Dept Agric. (1982).

76. Reij, C., Waters-Bayer, A.: Farmer innovation in Africa: a source of inspiration for agricultural development. (2014).

77. Norton, G., Alwang, J., Masters, W.: Economics of agricultural development: World food systems and resource use. (2014).

78. Freeman, P., Freeland, R.: Politics \&amp; technology: US polices restricting unmanned aerial systems in agriculture. Food Policy. (2014).

79. Mahant, M., Shukla, A., Dixit, S., Patel, D.: Uses of ICT in Agriculture. People. (2012). 